\title{
Dampak Perkembangan Teknologi Informasi dan Komunikasi terhadap Perilaku Intoleransi dan Antisosial di Indonesia
}

\section{Rafles Abdi Kusuma}

IAIN Syaikh Abdurrahman Siddik Bangka Belitung, Indonesia rafles.abdi@gmail.com

\begin{abstract}
The paper aims to exploration how the impact of the information and technology development in Indonesia. Especially, focus on the raising of the attitude and behavior that tend toward intolerant and antisocial. That behavior and attitude extremely were disturbing our social life. The flood of information in cyberspace causes disinformation that makes people split into poles of homogeneity, so people are not accustomed to a difference and are not trained to see problems from various sides. The transformation process taking place with a multilayer communication model has resulted in humans who are more individualistic and communalism, which leads to intolerant and antisocial behavior. Even today, communities are still divided into groups called "cebong" and "kampret". These two political poles cause people did not respect each other's differences. They spread hatred of speech and reject each other's activities, including worship activities. If this kind of social condition is allowed to leave, Indonesia will always be in an unsafe and comfortable condition. It should be prevented by knowing various characteristics or symptoms that arise from the behavior of people around us, both directly in the real world and through social media. Therefore, the authors offer a solution namely: strengthening the role of religion, especially in da'wa and internalization of the ideology of Pancasila, the enforcement of the constitution and humanist legal rules in Indonesia.
\end{abstract}

Keywords; the impact of ICT, Intolerances and antisocial behavior, the role of religion, Strengthening of nations.

\begin{abstract}
Abstrak
Artikel ini bertujuan untuk mengetahui bagaimana dampak dari perkembangan teknologi informasi dan komunikasi di Indonesia. Khususnya muncul sikap atau perilaku intoleran dan antisosial yang meresahkan kehidupan bermasyarakat. Banjir informasi di dunia maya menyebabkan disinformasi yang membuat masyarakat terpecah dalam kutub-kutub homogenitas, sehingga orang tidak terbiasa terhadap sebuah perbedaan dan tidak terlatih melihat persoalan dari berbagai sisi. Proses transformasi berlangsung dengan model komunikasi multilayer telah menghasilkan manusia yang lebih individualisme dan komunalisme, yang mengarah pada perilaku intoleran dan antisosial. Saat ini pun masih dirasakan masyarakat tepecah dalam kelompok-kelompok yang disebut "cebong" dan "kampret". Kedua kutub politik ini menyebabkan masyarakat tidak saling menghormati perbedaan. mereka saling menyebarkan ujaran kebencian dan saling tolak-menolak kegiatan apapun termasuk kegiatan beribadah. Apabila kondisi sosial seperti ini dibiarkan akan menjadikan Indonesia selalu dalam kondisi tidak aman dan nyaman. Seharusnya, hal tersebut dapat di cegah dengan mengetahui berbagai karakteristik atau gejala-gejala yang muncul dari perilaku orang-orang disekitar kita, baik secara langsung di dunia nyata maupun melalui media sosial. Oleh karena itu penulis menawarkan solusi seperti penguatan peran agama khususnya dalam komunikasi dakwah dan penanaman ideologi pancasila, penegakan konstitusi dan aturan hukum yang tegas di Indonesia.
\end{abstract}

Kata Kunci; Dampak TIK, Perilaku intolerasi dan antisosial, Peran agama, Penguatan kebangsaan. 
Citation: Rafles Abdi Kusuma, 'Dampak Perkembangan Teknologi dan Informasi terhadap Perilaku Intoleran dan Antisosial di Indonesia', Mawa'izh: Jurnal Dakwah dan Pengembangan Sosial Kemanusiaan, vol. 10, no. 2 (2019), pp. 273-290. 


\section{A. Pendahuluan}

eknologi informasi dan komunikasi telah mengubah dunia kita dalam berbagai cara dan kondisi sosial. Teknologi Informasi dan komunikasi (TIK) pun telah

banyak dipahami bahwa TIK membawa perubahan sosial. Perkembangan TIK membawa dampak seperti dapat merubah struktur organisasi dan nilai-nilai sosial yang berkaitan dengan bagaimana individu mengumpulkan, memproses, dan pertukaran informasi dengan individu lain. ${ }^{1}$

Bila dilihat dari esensi nilai informasi, informasi merupakan benda abstrak yang dapat dipergunakan untuk mencapai tujuan positif dan atau sebaliknya. Dimana informasi dapat mempercepat atau memperlambat pengambilan keputusan. Dengan demikian informasi memiliki kekuatan, baik yang membangun maupun yang merusak. Sementara teknologi informasi merupakan seperangkat fasilitas yang terdiri dari perangkat keras dan perangkat lunak yang dalam prakteknya diarahkan untuk mendukung dan meningkatkan kualitas informasi yang sangat dibutuhkan oleh setiap lapisan masyarakat secara cepat dan berkualitas. Berkat teknologi informasi inilah, informasi yang ada di setiap tempat pada detik yang sama dapat dipantau di tempat lain meskipun tempat itu berada di belahan bumi yang lain, atau bahkan di ruang angkasa sekalipun.

Pada lingkup kajian ilmu komunikasi, komunikasi adalah berbagi makna melalui pertukaran informasi. Proses komunikasi yang didefinisikan oleh teknologi komunikasi terdiri dari karakteristik pengirim dan penerima informasi. Terdapat makna dalam konteks budaya dan protokol komunikasi, serta ruang lingkup proses komunikasi. Makna yang dimaksud disini dapat dipahami dalam konteks hubungan sosial di mana informasi dan komunikasi diproses. ${ }^{2}$

Dalam konteks dampak perkembangan TIK terhadap kondisi sosial yang terjadi di Indonesia ialah penetrasi Internet yang sangat masif di Indonesia dimana data pada tahun 2018 menunjukkan sekitar 64,8 persen atau berjumlah 117,17 juta jiwa penduduk

\footnotetext{
${ }^{1}$ Everett M. Rogers, Communication technology (Simon and Schuster, 1986).

2 Manuel Castells et al., Mobile communication and society: A global perspective (Mit Press, 2009),
} p. 73. 
Indonesia sudah terhubung ke internet. ${ }^{3}$ Serta pertumbuhan yang cukup besar dari alat komunikasi berupa gadget atau smartphone di Indonesia, dimana gadget mengalami pertumbuhan yang sangat besar pada tahun 2018. Canalys adalah perusahaan riset atau analis pasar teknologi global mencatat bahwa jumlah smartphone yang di jual di Indonesia pada tahun 2018 mencapai 38 juta unit atau naik sekita 8,6 persen tiap tahunnya. ${ }^{4}$ Namun pertumbuhan tersebut dengan kondisi sosial di Indonesia tidak menunjukkan pertumbuhan yang sebanding lurus terhadap tingkat literasi digital masyarakat. Rendahnya literasi digital membuat masyarakat mengalami kesulitan dalam menyaring konten-konten positif karena pada dunia maya terjadi banjir informasi yang telah menghasilkan interaksi negatif antar pengguna, yang mendorong perilaku tidak bertanggung jawab. Salah satunya adalah fenomena anonimitas di dunia digital menunjukkan sikap yang bertentangan dengan nilai sosial masyarakat seperti penyebaran ujaran kebencian (hate speech), produksi dan penyebaran informasi palsu (hoaks) dan berbagai model penipuan online, serta kriminalitas. Anonimitas digital dikaji dari sebuah studi ilmu sosial menunjukkan bahwa seseorang dapat bertindak lebih agresif ketika ia yakin tidak akan dikenali atau diketahui. ${ }^{5}$

Pada sisi lain gadget yang selama ini paling banyak digunakan masyarakat untuk mengakses media sosial telah mendorong berkembangnya homogenitas masyarakat sehingga orang tidak terbiasa terhadap sebuah perbedaan dan tidak terlatih melihat persoalan dari berbagai sisi. Homogenitas ini mengarahkan masyarakat pada kutubkutub polarisasi yang saling bertentangan satu sama lain. ${ }^{6}$ Dengan kata lain, sifat homogenitas ini mampu mendorong sikap intoleransi pada masyarakat. Tentunya sikap dan perilaku intoleransi ini tidak sesuai pada masyarakat Indonesia yang membingkai

3 Wahyunanda Kusuma Pertiwi, 'APJII: Jumlah Pengguna Internet di Indonesia Tembus 171 Juta Jiwa', APJII: Jumlah Pengguna Internet di Indonesia Tembus 171 Juta Jiwa (16 May 2019), https://tekno.kompas.com/read/2019/05/16/03260037/apjii-jumlah-pengguna-internet-di-indonesiatembus-171-juta-jiwa, accessed 20 Nov 2019.

4 Wahyunanda Kusuma Pertiwi, '2018, Pasar Smartphone Indonesia Tumbuh Dua Digit', 2018, Pasar Smartphone Indonesia Tumbuh Dua Digit (1 Mar 2019), https://tekno.kompas.com/read/2019/03/01/16160037/2018-pasar-smartphone-indonesia-tumbuhdua-digit?page=all, accessed 20 Nov 2019.

5 Danielle Keats Citron and Helen Norton, 'Intermediaries and hate speech: Fostering digital citizenship for our information age', BUL Rev., vol. 91 (2011), p. 1447.

${ }^{6}$ Nuril Hidayah, 'Siskamling Digital: Melawan Intoleransi Melalui Gerakan Anti Hoaks', Ar-Risalah: Media Keislaman, Pendidikan dan Hukum Islam, vol. 16, no. 2 (2018), p. 89. 
nilai kebangsaan Indonesia dengan selalu mengedepankan Bhineka Tunggal Ika yang artinya walaupun berbeda-beda tapi tetap satu jua. Seperti yang terjadi saat kontestasi politik di Indonesia tahun 2019. Akibat dari "disinformasi"” yang begitu mudah tersebar di dunia maya, masyarakat di Indonesia terpecah belah dalam bahasa masyarakat maya yaitu antara "Cebong" dan "Kampret". Cebong disematkan kepada pendukung militan calon presiden nomor urut 01 yaitu Joko Widodo, sedangkan kampret ditujukan kepada pendukung militan calon presiden nomor urut 02 yaitu Prabowo Subianto. ${ }^{8}$ Jika dilihat pada Jagat media sosial pun, sampai hari ini masyarakat masih terbelah dengan kedua sebutan tersebut dan saling menunjukkan perilaku intoleransi.

Selain itu, dampak pemanfaatan gadget yang salah dikalangan pemuda telah membentuk generasi muda yang mengarah pada perilaku "dissenting personality"9 atau dengan kata lain adalah perilaku anti sosial. Perilaku ini muncul akibat dari kecanduan media sosial yang menyediakan pergaulan lebih bebas dan lebih luas tanpa harus mengetahui identitas asli, serta tidak ada batasan ruang dan waktu dengan siapa mereka berkomunikasi. Bahkan tidak jarang generasi milenial ini tidak menghiraukan sedang berada dimana mereka saat menggunakan media sosial dan bermain game.

Orientasi diri generasi tersebut pada ruang publik di dunia maya dengan di masyarakat nyata yang dirasakan semakin berkurang. Hal tersebut menjadi tanda atau gejala munculnya perilaku anti sosial pada generasi milenial. Dalam teori psikologi disebutkan bahwa pada dasarnya setiap individu memiliki "The need to belong" atau kebutuhan untuk memiliki rasa memiliki sosial, dimana mereka memiliki hubungan yang baik dengan orang lain adalah kebutuhan mendasar manusia. Artinya memiliki hubungan

7 'Arti Disinformasi dalam Kamus Besar Bahasa Indonesia (KBBI) Kamus versi online/daring (dalam jaringan)', disinformasi/dis'in'for·ma'si/ $n$ penyampaian informasi yang salah (dengan sengaja) untuk membingungkan orang lain: usaha subversi dapat dilakukan dengan menyusun -- yang dimuat dalam media massa (20 Nov 2019), https://kbbi.web.id/disinformasi, accessed 20 Nov 2019.

8 M. Tazri, 'Cebong dan Kampret dalam Pespektif Komunikasi Politik Indonesia', Perspektif Komunikasi: Jurnal Ilmu Komunikasi Politik dan Komunikasi Bisnis, vol. 3, no. 1 (2019), p. 2.

${ }^{9}$ Ivana Sajogo Didi Aryono Budiyono, 'KEPRIBADIAN ANTISOSIAL: FOKUS PADA WHITE-COLLAR CRIME', Jurnal Psikiatri UNAIR Surabaya, vol. 1, no. 1 (2012), p. 1. Dissenting Personality (kepribadian yang kerap berselisih) mewakili varian antisosial lingkup normal, sedikit lebih patologis. Melakukan segala hal dengan cara mereka sendiri, mau menanggung konsekuensinya, kadang bermain-main dengan batas hukum untuk mengejar tujuan/keinginannya. Mereka melihat diri sendiri sebagai orang merdeka, berotonomi. Otoritas dipandang rendah. Tidak suka rutinitas sehari-hari, impulsif, tidak bertanggung jawab, dapat memotivasi diri sendiri dan sangat kaya ide/kreatif. (Millon \& Davis, 2000). 
sosial yang kuat dapat sama pentingnya bagi kesehatan dan kebahagiaan manusia seperti kebutuhan sandang, pangan, papan.

Ada penelitian yang mendukung pendapat ini termasuk temuan bahwa memiliki hubungan sosial dapat meningkatkan peluang anda untuk bertahan hidup hingga 50\%. ${ }^{10}$ Oleh karena itu kesadaran generasi milenial atas perilaku anti sosial perlu di cermati. Sebagaimana banyak kejadian pada generasi milenial yang meninggal dunia akibat kecanduan berselancar ria di dunia maya, salah satunya adalah kecanduan bermain game online.

Selanjutnya dalam artikel ini, akan membahas lebih lanjut mengenai bagaimana dampak negatif perkembangan TIK yang menghasilkan perilaku Intoleransi dan anti sosial di Indonesia. Melalui berbagai studi kasus dan penggunaan teori yang berhubungan dengan ilmu komunikasi, psikologi dan sosiologi. Serta pembahasan kasus akan di balut dalam bingkai wacana Kesatuan dan Persatuan Negara Kesatuan Republik Indonesia (NKRI) dan perspektif kajian agama yang tentunya agama banyak mengajarkan nilai dan norma yang sejalan dengan kondisi sosial kekinian.

\section{B. Sifat Sosial dari TIK (The social nature of ICT)}

Bagaimana memahami perkembangan teknologi informasi dan komunikasi (TIK) dalam kontek perubahan yang terjadi dari nilai sosial, dapat dipahami pada konteks masyarakat jaringan global (network society). Beberapa tokoh yang membahas perubahan yang terjadi pada masyarakat jaringan antara lain, sebagai berikut:

\section{Perspektif Sistem}

Anthony Giddens dalam teori sistemnya menjelaskan masyarakat jaringan yang terbentuk dari perkembangan TIK merupakan sistem sosial yang dibentuk oleh persilangan berbagai sistem sosial. Giddens melihat sistem sosial disini sebagai sistem yang "terbuka". Dengan sifatnya yang terbuka tersebut memungkinkan adanya penetrasi serta kemungkinan terjadinya perubahan.

10 Mona Moieni, 'The Power of Social Belonging', The Power of Social Belonging (24 Sep 2015), https://www.psychologyinaction.org/psychology-in-action-1/2015/09/24/the-power-of-socialbelonging, accessed 20 Nov 2019. 
Pada akhir abad kedua puluh, ia berpendapat bahwa masyarakat telah memasuki era baru, dimana ilmu-ilmu sosial harus menanggapi dan mampu membawa masyarakat melampaui modernitas itu sendiri. Pada tahap perubahan dimasyarakat akibat dari perkembangan TIK, Giddens menyebutkan bahwa proses tersebut merupakan proses transisi, beberapa di antaranya merujuk pada nilai positif terhadap munculnya jenis baru sistem sosial. Giddens menyebutnya sebagai "masyarakat informasi" (information society) atau "masyarakat konsumen" (consumer society). ${ }^{11}$

\section{Perubahan Infrastruktur Sosial dan Media}

Pada perspektif perubahan yang terjadi terhadap infrastruktur sosial pada bentuk masyarakat jaringan. Van Dijk (2006) menjelaskan bahwa infrastruktur sosial berubah karena pengaruh jaringan telekomunikasi dan sebaliknya infrastruktur sosial dapat membentuk teknologi komunikasi. TIK telah membawa perubahan peradaban manusia menjadi kehidupan global "we live in a connected world, a second age, a human web, an a web society". ${ }^{12}$ Pada tingkat masyarakat dan dalam skala global, Van Dijk melihat bahwa jaringan media, jaringan sosial dan jaringan ekonomi telah membawa masyarakat mencapai ke sudut terjauh dan tepi dunia.

Dampak dari "connected" (teknologi menjadi "penghubung”) pada kehidupan dilihat Vand Dijk menjadi : "at the level of society and on a global scale we can see that media networks, social networks, and economic networks reach into the farthest corners and edges of the world. Our world has become truly globally connected".13

Dalam sejarah perkembangan media, beberapa revolusi komunikasi telah terjadi dari perkembangan TIK. Media mengalami perubahan mendasar yang dapat dibagi menjadi dua revolusi, yaitu revolusi komunikasi secara struktural dan revolusi komunikasi secara teknis. Pada diagram berikut ini van dijk menjelaskan revolusi yang terjadi pada media. ${ }^{14}$

Dalam revolusi komunikasi secara struktural, perubahan mendasar terjadi di koordinat ruang dan waktu. Media bisa menjadi bentuk komunikasi tetap dalam ruang

\footnotetext{
11 Frank Webster, Theories of the information society (Routledge, 2014).

12 Daniel Nehring and Ken Plummer, Sociology: An introductory textbook and reader (Routledge, 2014), p. 307.

13 Jan Van Dijk, The network society (Sage Publications, 2012), p. 2.

14 Ibid, p. 5.
} 
(di satu tempat) atau mereka dapat memungkinkan komunikasi antara tempat-tempat yang berbeda. Selain itu, mereka dapat memperbaiki saat komunikasi untuk waktu tertentu atau memungkinkan kita untuk menjembatani waktu.
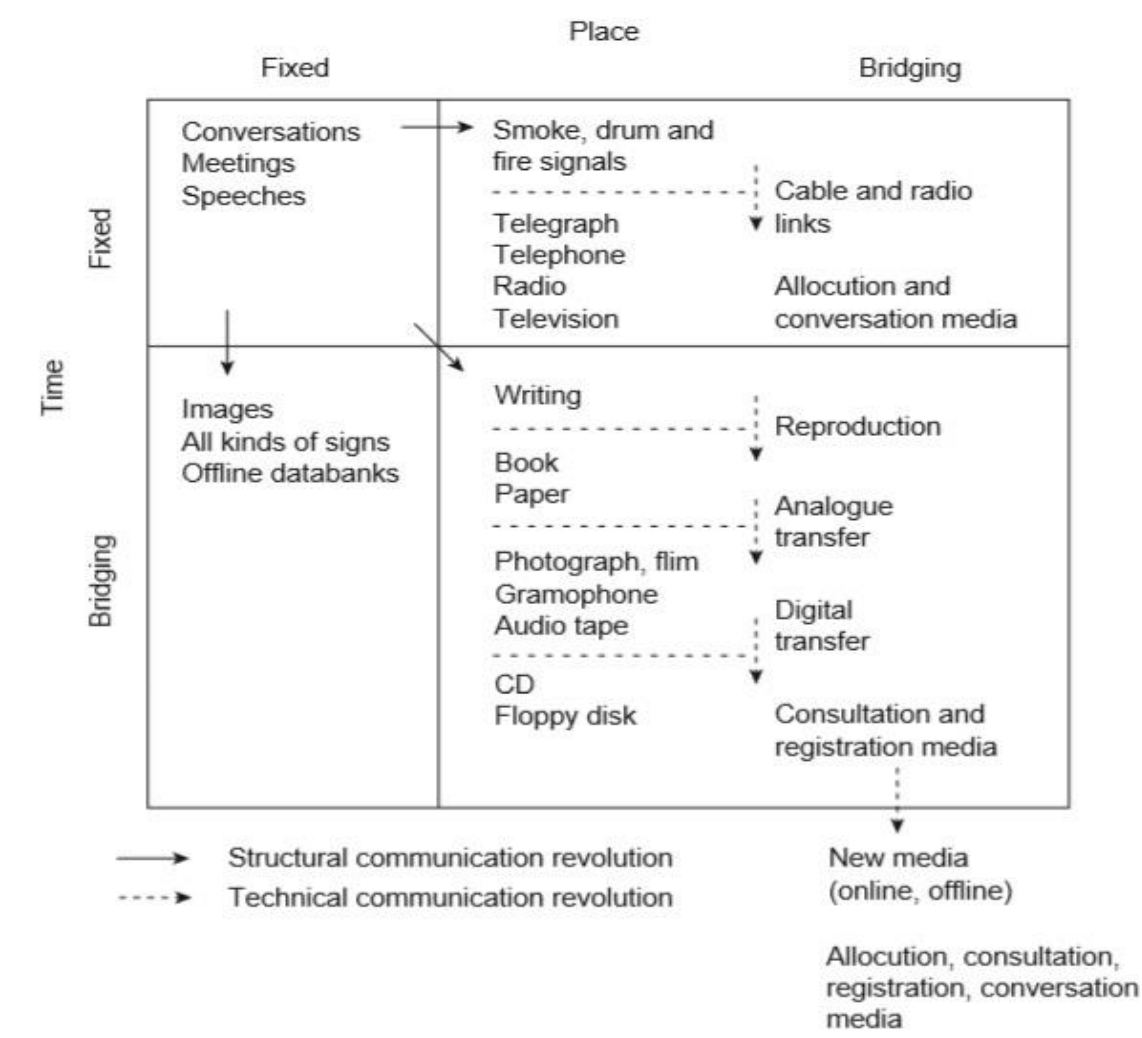

FIGURE I.I Communication revolutions in media history

Dalam revolusi komunikasi secara teknis, perubahan mendasar media terjadi dalam struktur koneksi, atau secara artifisial pada reproduksi isi media. Pengembangan mesin cetak adalah sebuah revolusi dalam reproduksi menulis. Pada paruh kedua abad ke-19 revolusi kedua terjadi, terutama perubahan teknis berdasarkan penemuan dan konstruksi sambungan jarak jauh dengan kabel dan udara, dan pengenalan analog baru serta teknik-teknik baru untuk reproduksi isi media.

\section{Interaksi dalam Network Society}

Jenkins melihat perkembangan TIK memiliki konsekuensi yang cukup besar bagi organisasi sosial dan perubahan budaya. Dimana terjadi interaksi manusia dengan teknologi yang didasari oleh ekspresi budaya yang diartikulasi pada semua bentuk 
komunikasi yang tergabungkan, dan interaktif atau disebut "konvergensi komunikasi". ${ }^{15}$ Konvergensi komunikasi diartikan oleh Manuel Castells sebagai sejumlah transformasi penting harus dilakukan di masing-masing dari dimensi proses komunikasi. Berbagai dimensi merupakan sistem, dan satu transformasi tidak dapat dipahami tanpa yang lain. Beberapa transformasi dari dimensi proses komunikasi yang disebut castells antara lain sebagai berikut:

Pertama, ada transformasi teknologi yang didasarkan pada digitalisasi komunikasi, jaringan komputer, perangkat lunak canggih, difusi yang meningkatkan kapasitas transmisi broadband, dan komunikasi dapat terjadi pada tingkat lokal maupun global melalui jaringan nirkabel (wireless) dengan bantuan akses internet.

Kedua, definisi dari pengirim dan penerima mengacu pada komunikasi dari struktur organisasi dan instansi. Khususnya komunikasi sosial, dimana pengirim dan penerima adalah media dan mereka disebut juga sebagai audiens (orang-orang yang diidentifikasi sebagai konsumen media).

Ketiga, dimensi budaya dari proses transformasi dilihat sebagai proses "multilayer komunikasi". Dalam hal ini dapat dipahami sebagai pertemuan dari dua pasang lapisan budaya yang bertentangan, yaitu pengembangan paralel antara budaya global dan beberapa identitas budaya. Budaya global dilihat sebagai proses simultan yang menghasilkan "individualisme". Sedangkan beberapa identitas budaya lain menghasilkan "komunalisme". ${ }^{16}$

Kedua hal ini saling berlawanan, namun dapat sama kuat sebagai pola budaya yang saat ini. Transformasi terkahir, Castells menyebutkan bahwa tiap komponen dari transformasi komunikasi merupakan ekspresi dari hubungan sosial. Kekuatan hubungan dari tiga transformasi tersebut diatas adalah yang mendasari evolusi dari sistem komunikasi multimodal "multimodal communication system". ${ }^{17}$

\section{Intoleransi di Indonesia}

${ }^{15}$ Castells et al., Mobile Communication and Society: A Global Perspective, p. 55.

16 Manuel Castells and Gustavo Cardoso, The Network Society: From Knowledge to Policy (Johns Hopkins Center for Transatlantic Relations Washington, DC, 2006).

17 Castells et al., Mobile Communication and Society: A Global Perspective, p. 57. 
Hari ini di era masyarakat informasi, banyak alasan untuk meragukan diri seseorang bahwa penelian diri sendiri yang merasa toleran terhadap orang lain yang berbeda bisa saja kebalikannya menunjukkan perilaku intoleran. Sebuah pendekatan filosofi etis dari semangat Socrates yang menggabungkan tiga hal, antara lain:

- Prinsip-prinsi politik mengungkapkan ekspresi rasa hormat yang sama bagi semua warga negara.

- Pemikiran kritis yang menemukan inkonsistensi, terutama yang berbentuk pembuatan pengecualian diri sendiri.

- Penanaman sistematis "mata batin" dengan kapasitas dari imajinatif memungkinkan kita membuat penilaian terhadap dunia dari sudut pandang seseorang yang berbeda baik agama maupun etnis.

Dari keutamaan etis Socrates diatas dapat membantu kita untuk melihat kerumitan dunia. Seperti yang terjadi pada negara-negara Eropa, intoleransi dapat dipahami dari berbagai kasus antara penduduk lokal dan imigran, antara muslim dan Nasrani. Hal ini disebabkan sudah tertanamnya homogenitas dan asimilasi budaya yang merupakan paradigma dominan masyarakat eropa, dimana "perbedaan adalah keasingan". ${ }^{18}$

Sejarawan George Mosse menyampaikan bahwa persatuan di Eropa sering diproyeksikan berfungsi untuk mendefinisikan bangsa terhadap elemen asing atau minoritas yang dicirikan sebagai sesuatu yang merosot dalam beberapa hal. Ia menyebut ini sebagai "a stigmatized sexuality" atau ibarat seksualitas yang distigma dari gagasan homogenitas. ${ }^{19}$

Dengan demikian kita melihat pada masyarakat Eropa seperti yang diungkapkan Socrates bahwa "mata batin" masyarakat Eropa sangat jelas terbingkai dalam nilai kesamaan. Pada perspektif seperti inilah intoleransi terjadi karena melihat keasingan sebagai sesuatu nilai perbedaan yang dapat mengikis kesatuan nasional dalam konteks homogenitas. Sehingga ekspresi rasa hormat yang sama bagi semua warga negara tidak dirasakan bagi kelompok-kelompok minoritas.

\footnotetext{
18 Martha C. Nussbaum, The New Religious Intolerance (Harvard University Press, 2012), p. 14.

19 Ibid.
} 
Jika dilihat dari hirarki kebajikan moral pada posisi tertinggi, dosa tertinggi adalah intoleransi. ${ }^{20}$ Carson mengungkapkan bahwa intoleransi bukan lagi berupa penolakan untuk membiarkan pendapat yang bertentangan untuk mengatakan bagian mereka didepan umum. Tetapi harus dipahami sebagai pertanyaan atau bertentangan dengan bagaimana pandangan bahwa semua pendapat nilainya sama dan pandangan dunia dianggap memiliki nilai yang sama. Selain itu, Carson mengungkapkan bahwa intoleransi telah dipandang sebagai nilai baru dari toleransi yang salah maksudnya adalah toleransi terjadi apabila melibatkan penolakan terhadap dogmatisme dan absolutisme, terdengar seperti tidak mengganggu sebuah dogmatis dan nilai-nilai absolut dalam suatu agama.

Definisi toleran-intoleran adalah sebuah "tindakan", bukan pikiran, apalagi menjadi sebuah aturan. Cohen menjelaskan toleran adalah tindakan yang disengaja oleh aktor dengan berprinsip menahan diri dari campur tangan (menentang) perilaku dalam situasi keragaman, sekalipun aktor tersebut percaya bahwa dia memiliki kekuatan untuk mengganggu.

Di dalam toleransi terkandung dua kata kunci, yang berperan sebagai prinsip, yaitu: Kesenjangan (intent) dan tidak-mengganggu (non-interfence). Russell Powell dan Steve Clarke dalam buku Religion, Tolerance and Intolerance: views from across the diciplines, memosisikan prinsip "tidak mengganggu" merupakan inti dari toleransi. Sikap tersebut haruslah bersifat "tidak mengganggu secara langsung" atau dengan "sengaja tidak mengganggu" (intent to non-interfere) terhadap orang lain maka seseorang bisa dikatakan toleran. Tentunya "sengaja" menjadi prinsip keharusan yang sangat penting karen jika seseorang tidak mengganggu orang lain yang berbeda hanya karena acuh dan abai, maka orang tersebut belum dapat dikatakan toleran.

Amin Mudzakkir seorang peneliti Lembaga Ilmu pengetahuan Indonesia (LIPI) memaparkan intoleransi politik di Indonesia diperkirakan menguat pada pemilu 2019. Hasil penelitian terhadap 1800 responden menjelang pemilu menunjukkan 57,8 persen responden mengatakan hanya akan memilih pemimpin yang seagama (dalam berbagai sekup mulai pimpinan level RT sampai presiden). ${ }^{21}$ Pemilihan pemimpin masih dinilai

${ }^{20}$ Donald A. Carson, The Intolerance of Tolerance (Wm. B. Eerdmans Publishing, 2012), p. 14.

21 Dylan Aprialdo Rachman Artikel ini telah tayang di Kompas. com dengan judul 'Intoleransi Politik Diperkirakan Semakin Menguat Jelang Pemilu 2019’ Sabrina Asril https://nasional.kompas. com/read/2018/12/07/19404801/intoleransi-politik-diperkirakan-semakin-menguat-jelang-pemilu- 
dari faktor agama bukan karena kinerjanya. LIPI menyebutkan ada tiga faktor yang mendorong intoleransi politik, yaitu : 1) Distrust karena ada perasaan terancam sehingga tidak percaya terhadap pihak lain yang berbeda; 2) Tingginya fanatisme keagamaan yang berbanding terbalik dengan rendahnya sekularitas; 3) Penggunaan media sosial yang semakin mendorong perasaan terancam, tidak percaya serta fanatisme keyakinan. Seperti isu kebangkitan Partai Komunis Indonesia (PKI) yang ramai diperbincangkan di media sosial. Dimana responden menyatakan 42,8 persen setuju dengan isu tersebut atau jika ada lima orang yang pernah mengetahui isu PKI dari media sosial berarti 2 atau 3 orang telah percaya terhadap informasi tersebut. ${ }^{22}$

Berbagai kasus Intoleransi terjadi di Indonesia pada tahun 2019 setidaknya terjadi 31 kasus dimana mayoritasnya adalah mengenai pelarangan ibadah. Data yang diungkapkan oleh sebuah LSM bernama Imparsial yang mengawasi dan menyelidiki pelanggaran Hak Asasi Manusia di Indonesia menyebutkan bahwa 12 kasus intoleransi terjadi berkaitan pelarangan atau pembubaran ritual pengajian ceramah atau pelaksanaan ibadah agama atau kepercayaan, 11 kasus terkait pelarangan beribadah, 3 kasus terkait perusakan rumah ibadah, 2 kasus pelarangan kebudayaan etnis tertentu. Serta kasus intoleransi lainnya terkait aturan tata cara berpakaian keagamaan, imbauan mewaspadai aliran tertentu, hingga penolakan bertetangga dengan agama lain. ${ }^{23}$

\section{Perilaku Anti Sosial di Indonesia}

Kebanyakan orang salah paham terhadap istilah "antisosial", selama ini banyak mengganggap bahwa orang yang antisosial adalah orang yang tidak banyak bergaul dan memilih sendirian. Padahal, orang dengan gangguan kepribadian antisosial adalah orang yang memenuhi kriteria berbeda-beda. Dari berbagai sumber mengatakan bahwa agar seseorang dapat didiagnosa mengalami gangguan kepribadian antisosial, maka orang

2019. Penulis :. Dylan Aprialdo Rachman, 'Intoleransi Politik Diperkirakan Semakin Menguat Jelang Pemilu 2019', Intoleransi Politik Diperkirakan Semakin Menguat Jelang Pemilu 2019 (7 Dec 2018), https://nasional.kompas.com/read/2018/12/07/19404801/intoleransi-politik-diperkirakan-semakinmenguat-jelang-pemilu-2019, accessed 20 Nov 2019.

22 Ibid.

${ }^{23}$ Matius Alfons, 'Imparsial: Ada 31 Kasus Intoleransi di Indonesia, Mayoritas Pelarangan Ibadah', Imparsial: Ada 31 Kasus Intoleransi di Indonesia, Mayoritas Pelarangan Ibadah (17 Nov 2019), https://news.detik.com/berita/d-4787954/imparsial-ada-31-kasus-intoleransi-di-indonesia-mayoritaspelarangan-ibadah, accessed 20 Nov 2019. 
tersebut haruslah berusia minimal 18 tahun dan memiliki gejala gangguan perilaku (conduct disorder) sebelum ia berusia 15 tahun. Gangguan perilaku ini meliputi perilaku melanggar norma sosial yang berulang dan menetap. Perilaku spesifik yang muncul dari conduct disorder ini dikategorikan menjadi empat yaitu : 1) Agresi terhadap manusia dan binatang; 2) Penghancuran properti atau berbagai alat-alat; 3) Penipuan atau pencurian; 4) Pelanggaran aturan berat atau yang serius.

Perilaku antisosial pada perspektif lain diungkapkan oleh Millon dan Davis bahwa terdapat variasi kepribadian antisosial, dimana ragam kombinasi gagasan ini diwariskan langsung oleh teori evolusi. Adapun lima variasi kepribadian antisosial menurut Theodore Millon antara lain: ${ }^{24}$ 1) Antisosial pencemburu (varian murni), perilaku ini selalu menyangkal dan merasa kekurangan, tamak serakah, iri, dengki, cemburu, suka mencari ganti rugi, dan selalu ingin mendapat dari pada memberi; 2) Antisosial Penjaga Reputasi (ciri narsistik), perilaku ini seperti tidak mau dianggap cacat, rapuh, tak terkalahkan, tidak dapat diganggu gugat, bersikeras ketika statusnya dipertanyakan, serta tidak mau diremehkan; 3) Antisosial Pengambil Resiko (ciri histrionik), perilaku ini sering menunjukkan rasa tidak takut, berani, suka berpetualang, sembrono, membabibuta, impulsif dan tidak peduli terhadap bahaya/ resiko; 4) Antisosial Nomadis (ciri skicoid, acoidant), Perilaku yang sering muncul adalah sering merasa bernasib sial/buruk, dianggap tidak penting, tidak diinginkan, gelandangan/tunawisma, impulsif namun tidak berbahaya; 5) Antisosial Pendengki (ciri sadistik, paranoid), perilaku yang suka berkelahi, penuh dendam, kejam, sangat jahat, brutal, sering mengantisipasi penghianatan dan hukuman, tempramen kasar dan tidak berperasaan, tidak merasa takut bersalah.

Dari lima variasi antisosial diatas, kita bisa memahami pada kategori antisosial mana diri kita atau orang lain disekitar kita. Tentunya tidaklah susah mengidentifikasikannya, dari penjelasan diatas sangat jelas tanda-tanda perilaku yang muncul untuk mengatakan bahwa perilaku antisosial telah tertanam pada diri. Namun pada akhirnya antisosial ini bisa dipahami dengan perspektif kognitif, dimana kembali pada epistimologi bahwa cabang filsafat berkaitan dengan sifat pengetahuan, bagaimana

${ }^{24}$ Millon T. Davis R, The Antisocial Personality', in Personality Disorder in Modern Life (New York: John Wiley \& Sons Inc), p. 102. 
pengetahuan diperoleh dan apa batasannya. Asal kata "kognitif" dari bahasa latin yaitu "cognitare" yang berarti "telah diketahui". Sehingga muncul pertanyaan "bagaimana cara kita belajar", "apa yang bisa kita pelajari" dan "bagaimana sensasi dan persepsi yang terkait", atau pertanyaan lain seperti "bagaimana kita bisa memverifikasi penilaian kita". Tentunya pertanyaan-pertanyaan ini sangat berhubungan dengan studi tentang kognisi dan perkembangan manusia pada kehidupan sehari-hari. Faktanya, karena anda tidak akan pernah berpikir atau merasakan apa pun yang tidak memerlukan representasi mental. Oleh karena itu psikologi kognitif telah mengusulkan bahwa kognisi dianggap sebagai model integratif untuk kepribadian..$^{25}$

Berbagai kasus berhubungan tentang perilaku antisosial di Indonesia diantaranya adalah salah satunya kasus kekerasan Audrey (siswi sekolah menegah pertama atau SMP) di Pontianak yang berusia 14 tahun, yang dilukai oleh 12 orang siswi sekolah menengah atas (SMA). Psikolog Dra. Irna Minauli, M.Si berpendapat tentang kasus ini bahwa menunjukkan suatu bentuk kekerasan di luar nalar atau dikategorikan sebagai extraordinary crime. Perilaku kekerasan ini jika dilakukan oleh orang dewasa dapat dikatakan sebagai gangguan kepribadian antisosial atau antisocial personality disorder. Tetapi karna pelaku masih berusia dibawah 18 tahun maka termasuk kategori gangguan perilaku (conduct disorder) dan ini tanda-tanda telah terbentuk gangguan perilaku antisosial yang dulu dikenal dengan istilah psikopat. ${ }^{26}$

Selain itu kasus perilaku antisosial seperti yang terjadi pada tahun 2017 lalu di Medan, dimana Andi Lala berusia 34 tahun merupakan warga desa Sekip, kecamatan Lubuk Pakam, kabupaten Deli Serdang Sumatera Utara, yang menjadi tersangka utama pembunuhan 5 orang dalam satu keluarga di kelurahan Mabar. Pada kasus ini ia dibantu juga oleh istrinya dan satu orang temannya. Pembunuhan ini dilakukan atas motif balas dendam. Psikolog Dr. Netty Damayanti, S.Psi, M,Psi, psikolog mengungkapkan bahwa pelaku tergolong orang yang berkepribadian antisosial. Pelaku tidak merasa kesal sedikitpun setelah melakukan tindakan kriminal kepada orang lain dan telah

25 Theodore Millon et al., Personality disorders in modern life (2004), p. 48-53.

26 Anita Sinuhaji, Psikolog: Kasus Audrey Kejahatan di Luar Nalar (10 Apr 2019), https://medaninside.com/psikolog-kasus-audrey-kejahatan-di-luar-nalar/, accessed 20 Nov 2019. 
melakukan pelanggaran hukum. ${ }^{27}$ Dalam kontens kategori antisosial Theodore Millon, hal tersebut termasuk kategori antisosial pendengki karena menunjukkan perilaku sangat kejam, melawan hukum dan penuh dendam. Tentunya kasus-kasus seperti ini perlu diwaspadai dan perlu diperhatikan dengan seksama berbagai gejala yang muncul dari seseorang yang bisa berpotensi melakukan kejahatan dari perilaku anti sosial.

Adapun selain kasus diatas, berbagai kasus lainnya bahkan menunjukkan adanya penggunaan media sosial dalam melakukan tindakan perilaku antisosial. Seperti penembakan oleh teroris kepada umat muslim pada sebuah masji di Selandia Baru yang menayangkan videonya setelah membantai jamaah yang sedang beribadah. Pelaku juga menunjukkan rasa tidak bersalah setelah melakukannya. Ada lagi kasus yang pembunuhan keji kepada gadis berusia 17 Tahun bernama Bianca Devins di New York, dimana polisi menemukan pelakunya adalah Clark pacarnya yang bertemu dari hasil interaksi melalui media sosial instagram. Pada saat menghadiri konser bersamasama, lelaki pasangannya meng-unggah foto pembunuhan tersebut di Instagramnya yang kemudian menjadi viral dengan caption "Maaf, Bianca”. ${ }^{28}$

\section{E. Peran Agama dan Wawasan Kebangsaan}

Iann Accone mendefinisikan agama sebagai "seperangkat kepercayaan, kegiatan dan apa pun yang dimiliki institusi bersama yang didasarkan atas kepercayaan pada supranatural". ${ }^{29}$ Dalam dekade terakhir, peran agama dalam perilaku ekonomi dan sosial telah menjadi fokus baru neo-klasik berbagai penelitian ekonomi dan sosial yang mengembangkan model permintaan dan pasukan agama dan dampaknya menjadi religius pada perilaku tertentu.

27 Antara Rahmad, 'Pelaku Pembantaian di Medan Memiliki Kepribadian Antisosial', Pelaku Pembantaian di Medan Memiliki Kepribadian Antisosial (24 Apr 2017), https://www.beritasatu.com/nasional/426992/pelaku-pembantaian-di-medan-memiliki-kepribadianantisosial, accessed 20 Nov 2019.

${ }^{28}$ Harian Inhua Online, 'Banyaknya Kasus Pembunuhan Disiarkan di Media Sosial, Facebook, Instagram dkk Perlu Bebenah', Banyaknya Kasus Pembunuhan Disiarkan di Media Sosial, Facebook, Instagram dkk Perlu Bebenah (17 Jul 2019), https://www.harianinhuaonline.com/banyaknya-kasuspembunuhan-disiarkan-di-media-sosial-facebook-instagram-dkk-perlu-bebenah/, accessed 20 Nov 2019.

${ }^{29}$ Stephan Bartke and Reimund Schwarze, 'Risk-averse by nation or by religion? Some insights on the determinants of individual risk attitudes', Some Insights on the Determinants of Individual Risk Attitudes (October 2008). SOEP paper, no. 131 (2008). 
Miller juga mengemukakan bahwa keyakinan agama sebagai perilaku yang dapat menghidari risiko yang dipilih secara rasional yang didorong oleh keyakinan masyarakat, bahwa agama tertentu dan perilaku yang menyertainya diperlukan untuk memastikan kehidupan setelah kematian. Miller menemukan hubungan antara partisipasi aktif dalam iman dan agama dengan risiko keengganan dalam masyarakat monoteistik. Masyarakat ateis memiliki kesepahaman bahwa agama hanya memiliki efek kecil pada penghindaran resiko. Tentunnya hal ini tidak sesuai dengan peradaban yang dibangun dengan nilainilai toleransi yang mengedepankan agama sebagai kekuatan supranatural pembentuk perilaku yang tidak bertentangan dengan kondisi sosial.

Dalam konteks mengantisipasi dampak perkembangan TIK yang menghasilkan perilaku intoleransi dan antisosial di masyarakat, tentunya agama memainkan peran penting. Secara umum dalam prinsip berdakwah, yang disebutkan dalam QS. An-Nahl : 125 ada tiga hal prinsipil, yaitu : 1) Bil-hikmah, 2) Bil-Mauidah hasanah, 3) Mujadalah Bilahsan. $^{30}$

Dalam tujuan membangun kesatuan dan persatuan bangsa, dampak perkembangan TIK juga perlu dilakukan penguatan nilai-niai kebangsaaan seperti penguatan terhadap idoelogi pancasila dan konstitusi. Serta diperlukan kesadaran masyarakat untuk menegakkan azas dan aturan hukum yang berlaku. Adapun konsensus yang menjamin tegaknya konstitualisme di era digital $4.0 \mathrm{ini}$, yang umumnya dipahami bersandar pada tiga elemen kesepakatan (consensus), yaitu: 1) Kesepakatan tentang tujuan cita-cita bersama (the goals of society or general acceptance of the same philosophy of government); 2) Kesepakatan atas the tule of law atau sebagai landasan pemerintahan

${ }^{30}$ Hajir Tajiri, 'Dakwah dan Pengembangan Kendali Diri: Upaya Antisipasi Kecenderungan Seks Bebas Remaja', Ilmu Dakwah: Academic Journal for Homiletic Studies, vol. 5, no. 15 (2010), p. 1030. Asep Muhyidin8 menjelaskan prinsip-prinsip itu sebagai: dakwah bil-hikmah mengandung pengertian: dakwah bijak, memperhatikan suasana, situasi dan kondisi mad"u, menggunakan metode yang relevan dan realistis sesuai tantangan dan kebutuhan, memperhatikan kadar pemikiran dan intelektual, suasana psikologis dan situasi sosial-kultural mad"u. Dakwah bil-mauidzah hasanah dapat mengandung maksud sebagai dakwah dengan tutur kata yang lembut, menghindari sikap sinis dan kasar, tidak menyebutnyebut kesalahan atau menghakimi orang yang diajak bicara. Sedangkan dakwah bil mujadalah dimaksudkan sebagai dakwah dengan cara berdiskusi atau debat dengan prinsip: tidak merendahkan pihak lawan, menghina, mengejek, menghujat, bukan untuk mencari kemenangan tapi untuk mencapai kebenaran, bertujuan semata-mata untuk menunjukkan kebenaran sesuai nilai-nilai ajaran Islam, tetap menghormati pihak lawan dan tidak ada pihak yang merasa diri kalah dalam perdebatan. 
atau penyelenggaraan negara; 3) Kesepakatan tentang bentuk institusi dan prosedur ketatanegaraan (the form of institutions and procedures).$^{31}$

\section{F. Penutup}

Perkembangan Teknologi Informasi dan Komunikasi merupakan suatu keniscayaan yang tidak dapat ditolak dari kemajuan peradaban. Sekarang ini pertumbuhan alat komunikasi dan informasi berupa perangkat keras (hardware) maupun perangkat aplikasi (software) banyak memberikan manfaat berikut juga tantantan bagi kondisi sosial dan agama. Munculnya perilaku-perilaku menyimpang seperti intoleransi dan antisosial menjadi tantangan yang perlu diwaspadai bagi generasi mendatang. Tentunya generasi milenial perlu diberikan penguatan nilai-nilai agama dan kebangsaan agar tidak terjerat pada kasus-kasus yang merupakan bentuk degradasi moral.

Berbagai kasus intoleransi dan antisosial di Indonesia menjadi catatan khusus bagi berbagai pihak seperti akademisi, pemerintah, aparat penegak hukum. Agar Indonesia tetap damai, aman dan semakin maju. Sebagaimana misi pengembangan sumber daya manusia yang diusung pemerintah yaitu "SDM Unggul Indonesia Maju”. Tentunya perlu usaha yang sistematis dan konsisten untuk sama-sama membangun SDM Indonesia yang unggul dengan tidak menunjukkan sikap intoleransi dan antisosial pada kehidupan bermasyarakat. Selain itu diharapkan berbagai model pembelajaran yang sesuai dengan generasi milenial atau selaras antara pengembangan Ilmu Pengetahuan dan Teknologi (IPTEK) dan Pendidikan Agama. Sehingga tidak ada ketimpangan antara pengembangan softskill dan hardskill generasi muda Indonesia yang bertujuan untuk membangun daya saing sumber daya manusia Indonesia yang unggul dalam keilmuan, karya-karya ilmiah dan seni, serta berbagai prestasi lainnya.

${ }^{31}$ S.H. Jimly Asshiddiqie, Ideologi, Pancasila, dan Konstitusi (2008), p. 6. 


\section{Daftar Pustaka}

Alfons, Matius, 'Imparsial: Ada 31 Kasus Intoleransi di Indonesia, Mayoritas Pelarangan Ibadah', Imparsial: Ada 31 Kasus Intoleransi di Indonesia, Mayoritas Pelarangan Ibadah, 17 Nov 2019, https://news.detik.com/berita/d-4787954/imparsial-ada31-kasus-intoleransi-di-indonesia-mayoritas-pelarangan-ibadah, accessed 20 Nov 2019.

'Arti Disinformasi dalam Kamus Besar Bahasa Indonesia (KBBI) Kamus versi online/daring (dalam jaringan)', disinformasi/dis'in'for'ma'si/ $n$ penyampaian informasi yang salah (dengan sengaja) untuk membingungkan orang lain: usaha subversi dapat dilakukan dengan menyusun -- yang dimuat dalam media massa, 20 Nov 2019, https://kbbi.web.id/disinformasi, accessed 20 Nov 2019.

Bartke, Stephan and Reimund Schwarze, 'Risk-averse by nation or by religion? Some insights on the determinants of individual risk attitudes', Some Insights on the Determinants of Individual Risk Attitudes (October 2008). SOEPpaper, no. 131, 2008.

Carson, Donald A., The intolerance of tolerance, Wm. B. Eerdmans Publishing, 2012.

Castells, Manuel et al., Mobile communication and society: A global perspective, Mit Press, 2009.

Castells, Manuel and Gustavo Cardoso, The network society: From knowledge to policy, Johns Hopkins Center for Transatlantic Relations Washington, DC, 2006.

Citron, Danielle Keats and Helen Norton, 'Intermediaries and hate speech: Fostering digital citizenship for our information age', BUL Rev., vol. 91, 2011, p. 1435.

Davis R, Millon T., The Antisocial Personality', in Personality Disorder in Modern Life, New York: John Wiley \& Sons Inc.

Didi Aryono Budiyono, Ivana Sajogo, 'KEPRIBADIAN ANTISOSIAL: FOKUS PADA WHITECOLLAR CRIME', Jurnal Psikiatri UNAIR Surabaya, vol. 1, no. no 1, 2012, p. 1.

Harian Inhua Online, 'Banyaknya Kasus Pembunuhan Disiarkan di Media Sosial, Facebook, Instagram dkk Perlu Bebenah', Banyaknya Kasus Pembunuhan Disiarkan di Media Sosial, Facebook, Instagram dkk Perlu Bebenah, 17 Jul 2019, https://www.harianinhuaonline.com/banyaknya-kasus-pembunuhan-disiarkandi-media-sosial-facebook-instagram-dkk-perlu-bebenah/, accessed 20 Nov 2019.

Hidayah, Nuril, 'Siskamling Digital: Melawan Intoleransi Melalui Gerakan Anti Hoaks', ArRisalah: Media Keislaman, Pendidikan dan Hukum Islam, vol. 16, no. 2, 2018, pp. 88-98.

Jimly Asshiddiqie, S.H., Ideologi, Pancasila, dan Konstitusi, 2008.

Kusuma Pertiwi, Wahyunanda, '2018, Pasar Smartphone Indonesia Tumbuh Dua Digit', 2018, Pasar Smartphone Indonesia Tumbuh Dua Digit, 1 Mar 2019, https://tekno.kompas.com/read/2019/03/01/16160037/2018-pasarsmartphone-indonesia-tumbuh-dua-digit?page=all, accessed 20 Nov 2019.

----, 'APJII: Jumlah Pengguna Internet di Indonesia Tembus 171 Juta Jiwa', APJII: Jumlah Pengguna Internet di Indonesia Tembus 171 Juta Jiwa, 16 May 2019, 
https://tekno.kompas.com/read/2019/05/16/03260037/apjii-jumlahpengguna-internet-di-indonesia-tembus-171-juta-jiwa, accessed 20 Nov 2019.

Millon, Theodore et al., Personality disorders in modern life, 2004.

Moieni, Mona, 'The Power of Social Belonging', The Power of Social Belonging, 24 Sep 2015, https://www.psychologyinaction.org/psychology-in-action1/2015/09/24/the-power-of-social-belonging, accessed 20 Nov 2019.

Nehring, Daniel and Ken Plummer, Sociology: An introductory textbook and reader, Routledge, 2014.

Nussbaum, Martha C., The new religious intolerance, Harvard University Press, 2012.

Rahmad, Antara, 'Pelaku Pembantaian di Medan Memiliki Kepribadian Antisosial', Pelaku Pembantaian di Medan Memiliki Kepribadian Antisosial, 24 Apr 2017, https://www.beritasatu.com/nasional/426992/pelaku-pembantaian-di-medanmemiliki-kepribadian-antisosial, accessed 20 Nov 2019.

Rogers, Everett M., Communication technology, Simon and Schuster, 1986.

Sabrina Asril, Dylan Aprialdo Rachman Artikel ini telah tayang di Kompas. com dengan judul 'Intoleransi Politik Diperkirakan Semakin Menguat Jelang Pemilu 2019', https://nasional.kompas. com/read/2018/12/07/19404801/intoleransipolitik-diperkirakan-semakin-menguat-jelang-pemilu-2019. Penulis :. Dylan Aprialdo Rachman, 'Intoleransi Politik Diperkirakan Semakin Menguat Jelang Pemilu 2019', Intoleransi Politik Diperkirakan Semakin Menguat Jelang Pemilu 2019, 7 Dec 2018, https://nasional.kompas.com/read/2018/12/07/19404801/intoleransi-politikdiperkirakan-semakin-menguat-jelang-pemilu-2019, accessed 20 Nov 2019.

Sinuhaji, Anita, Psikolog: Kasus Audrey Kejahatan di Luar Nalar, 10 Apr 2019, https://medaninside.com/psikolog-kasus-audrey-kejahatan-di-luar-nalar/, accessed 20 Nov 2019.

Tajiri, Hajir, 'Dakwah dan Pengembangan Kendali Diri: Upaya Antisipasi Kecenderungan Seks Bebas Remaja', Ilmu Dakwah: Academic Journal for Homiletic Studies, vol. 5, no. 15, 2010, pp. 1023-68.

Tazri, M., 'CEBONG DAN KAMPRET DALAM PESPEKTIF KOMUNIKASI POLITIK INDONESIA', Perspektif Komunikasi: Jurnal Ilmu Komunikasi Politik dan Komunikasi Bisnis, vol. 3, no. 1, 2019, pp. 1-7.

Van Dijk, Jan, The network society, Sage Publications, 2012.

Webster, Frank, Theories of the information society, Routledge, 2014. 